\title{
Property rights, institutional change and development in South Africa
}

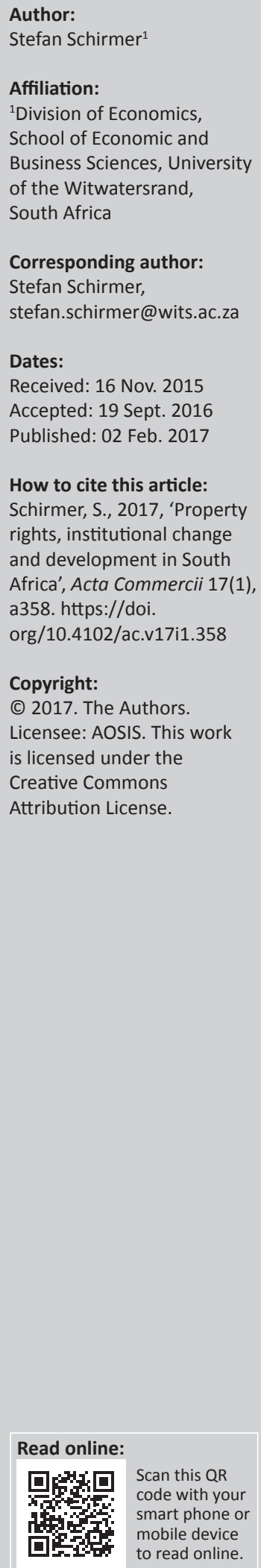

Orientation: This article examined the link between property rights and development in the context of South Africa.

Research purpose: The article sought to unpack the implications of Hernando De Soto's work and the broader institutional economics literature for the policy challenges that South Africa currently confronts.

Motivation for the Study: Hernando De Soto's call for a property rights system accessible to all has had a limited impact in South Africa even though his arguments linking poverty to limited property rights systems seems highly relevant here. This is a legacy of Apartheid that has not yet been properly tackled. At the same time, South African realities may raise questions about De Soto's conclusions and his policy recommendations.

Research design: The article provided a textual analysis of De Soto's work and then applied it to an investigation of South African poverty and the policies that have been implemented since 1994. The article also drew on seminal contributions to institutional economics to shed light on the process of institutional change, and then showed how this perspective fits with much of what De Soto has written about transforming property rights systems.

Main findings: This article argued that extending property rights to all is vital for development and for overcoming a major legacy of apartheid. However, moving from a restricted to a universal system requires fundamental institutional changes that are difficult to achieve.

Contribution: While De Soto has often advocated a top-down, overly simplistic policy approach in the past, this article showed that the necessary changes can only come about via an incremental, bottom-up approach. To this end, it is particularly important to strengthen the accountability and capacity of local government.

\section{Introduction}

When Hernando De Soto visited South Africa in 2006, he pointed to what he believed was the country's fundamental problem. He admitted to knowing little about South Africa's 'economic framework', but nevertheless described it as two separate economies, one for the rich under the dome-like protection of an integrated property rights system, and the other outside of that protection and for the poor. He called this the 'bell-jar effect'. The solution he prescribed was to 'legalise' the poor so that they could be assimilated into the mainstream economy. ${ }^{1}$

His visit elicited some support from within the upper echelons of government and either indifference or rejection from academics. Minister of Human Settlements, Lindiwe Sisulu, was impressed at that time and has recently drawn attention to the influence De Soto has had on South Africa's housing policy. She supports the extension of property rights to the poor and wants to reduce their dependence on government. However, despite these stated intentions, and perhaps because of a certain level of ambiguity within the department, only 1.44 million (50\%) of the estimated 2.94 million subsidised housing units that had been delivered by 2010 were on the deeds registry. ${ }^{2}$

Those academics who reacted to De Soto's visit - mostly experts on land reform and housing rejected the idea that providing the poor with title deeds would promote development. They pointed to the increased vulnerability that poor people would face if they either had to pay off a mortgage or were tempted to raise loans using their property as collateral. They also argued that less formal, communal-type rights provided vulnerable people with security that would be 1.Absence of Property Rights Slows Integration - De Soto https://cp.uspdesigns.co.za/www.cyberprop.com/newsletter_06052005.shp 2.Soula Proxenos, Title deeds for subsidised housing will build wealth in SA on grand scale, http://www.biznews.com/africa/2014/11/19/ 
destroyed if rights became 'individualised'. They expressed concern about the potential for conflict that would emerge via a top-down entitlement process in the context of overlapping claims on pieces of land (Cousins et al. 2005; Tomlinson 2005).

The problem with all of this, I will argue in this article, is that De Soto has - largely as a result of his tendency to swoop into countries as the high-level expert who tells governments what to do - created an impression that overcoming the belljar effect involves a simple process of handing out title deeds.

My reading of De Soto's work leads me to a different conclusion. I will demonstrate that, in his books, De Soto depicts the kind of property rights system that will generate development as the product of extremely complex institutional changes. These changes, I will argue, are likely to be pathdependent and can only emerge as a result of political shifts within all levels of the state. Given these difficulties, title deeds are unlikely to be a panacea. Nevertheless, as part of a broader development process, there are ways in which the property rights system can be improved, which will strengthen the prospects for development and expand the opportunities available for the poor.

\section{What are property rights?}

Property rights provide individuals with protection from expropriation, the right to buy and sell the thing that is owned at a time of their own choosing, an asset that can be used to secure loans, the right to enjoy and enhance the benefits of that which is owned and the ability to exclude others from sharing those benefits.

In the narrow sense, property rights as protection from expropriation are a very old phenomenon. For example, Angeles (2011:9) has shown that English kings found it difficult to expropriate land. Centuries of traditions and explicit laws protected the property rights of land holders, even in feudal times. He goes on to point out that the Glorious Revolution, which strengthened the rights of parliament and property owners in relation to the King, and which many economists (Acemoglu \& Robinson 2012:102-104; North \& Weingast 1989) have identified as decisive in laying the groundwork for economic take-off, had no effect on already secure English property rights. McCloskey (2010) had similarly employed the ancient nature of property rights to dismiss the arguments of the 'institutional school' led by Douglass North.

In contrast to these assertions about the ancient origins of property rights, De Soto (2001:112) has argued that property systems open to all citizens are a relatively recent phenomenon. Western nations, he argues, finalised a process of widespread property reform about a century ago. In Japan, he maintains further, such a system has been in place for less than 50 years, and in many developing nations it does not exist at all. Clearly, De Soto and Angeles are talking about two different things. Angeles is talking about the existence of security for property owners, whereas De Soto is talking about the openness and accessibility of the property system. In addition, Angeles' focus is essentially on de facto rights, whereas, as we shall see, De Soto is talking about a general acceptance, across society, of property rights as an abstract concept.

Security is not the same thing as accessibility. In fact, it may be necessary to compromise security of tenure in order to make property rights more accessible. As Acemoglu and Robinson (2012:75) have pointed out, the 175 plantation owners who dominated colonial Barbados, had well-defined, secure and enforced property rights. However, the vast majority of the population were excluded from the property system and from accessing new economic opportunities to lift themselves out of poverty. To achieve inclusive growth, Acemoglu and Robinson argued that countries need both secure property rights and economic opportunities. What Acemoglu and Robinson do not explain is how, in a place like colonial Barbados, it could have been possible to transform the property rights regime without undermining the security of those rights. How, in other words, should countries move from de facto property rights for the few to the general acceptance of property as an abstract right that should apply to all citizens?

Hernando De Soto's core message, especially in The Mystery of Capital, is that prosperity and inclusion are predicated on the expansion of secure property rights and the general acceptance of individual rights to property at an abstract level. In many passages of his written work, De Soto recognises that this is an extremely complex process. What distinguishes a good property system, he argues, is that it is 'mind friendly'. He means that a good property system organises knowledge about assets in such a way that the general population can understand and make use of this knowledge. He sees formal property systems as instruments of thought. They turn the things that people own into a registered asset in a way that is accessible and understandable for ordinary people. Assets can then be used to generate additional value. It is, furthermore, only when everyone can gain access and use formal property systems that they effectively establish a social contract within which everyone can cooperate to raise the productivity of society (De Soto 2001:232, 231).

The process that De Soto is describing required fundamental institutional changes in the West and still requires those changes in most developing countries today, especially in South Africa, which is still grappling with the legacies of our apartheid past. De Soto's perspective on property rights goes much further than simply protecting those who have property from expropriation, or even providing some people without title with a de facto deed that is registered at a government office. If De Soto's vision is to be realised, countries need to experience an institutional transformation. How such a transformation comes about has not been accorded sufficient attention in the literature, including, as we shall see, in De Soto's own work. 
How should those in favour promoting higher and more inclusive growth in developing countries set out to achieve such institutional changes? I will argue that there are no easy answers. The insights from institutional economics reveal that institutions can and do change, but usually in a pathdependent way, and never in a straightforward manner initiated by government planners with good intentions. After drawing out the lessons from institutional economics and applying them to an interpretation of De Soto's development perspective, the article considers what could be done in South Africa.

\section{Determinants of institutional change}

If we want to understand what recent debates in institutional economics can tell us about the types of transformations De Soto's development approach requires, we need to start with the work of Douglass North. In founding what was at the time called 'the new institutional economics', North was primarily seeking to place individual economic choices into a social context (North 1993:244-245). He saw that introducing space, time and uncertainty into economic models creates the challenge of cooperation. He put forward 'institutions' as the solutions to this challenge as they make it easier/cheaper to cooperate while also raising the cost of defection. From this starting point, North defined institutions as the informal constraints, formal rules and modes of enforcement that structure economic activities. North's work has emphasised the importance of institutions in incentivising productive behaviour and preventing bad behaviour (especially violence), thus channelling initiatives into the patterns that enhance welfare and prosperity.

There are different perspectives on where such institutions come from and how they change. In his early work, North adopted an individualistic, functionalist perspective on how institutions required to solve prevailing collective action problems emerged. He argued that human beings have generally devised institutions to create order and reduce uncertainty in exchanges (quoted in David 1994:207). He conceived these beings as maximising individuals who, in response to economic needs, deliberately set out to reduce transaction costs as much as possible. In this way, Douglass North's early writing underestimated the extent to which pre-existing institutions matter in structuring the way that individuals chose to change those institutions (see, e.g., North 1977:715).

This early position of North went against an older, less orthodox tradition in economics that emphasised the ways in which individual decisions are socially constructed without denying the importance of individual choices. John Commons (1950) was a prominent proponent of this older view. He believed that collective action not just creates restrictions on certain forms of behaviour but also gives individuals the capacity to act. He argued that institutions emerge out of a process of collective action that provided people with a sense of security as well as greater control over both their present environment and the future.

Collective action, Commons argued, allows people to take on the risky ventures that individuals working in isolation from one another would mostly avoid. In his terms, collective action facilitates the expansion of an individual's capacity beyond what they can do by their 'own puny acts' (quoted in Vanberg 1989:345). As an example of this, he spoke of a union leader in 19th century New York who transformed street cleaners from dirty, despised and subservient individuals into professional, well-dressed and respected 'sanitary workers'. This was achieved by organising them, giving them a sense of pride and providing them with clean uniforms. Thus, Commons saw individuals as inseparable from the relations and changing forms of collective action of which they were part and out of which they emerged (Commons 1950:117).

In a similar vein, the post-Keynesian economist G.L.S. Shackle has pointed to the role of uncertainty in placing limits on the kind of individualistic maximising behaviour on which North's work was originally predicated. Under uncertain circumstances, Shackle (1990:331) argued that rational people will avoid investments that derive their value from fortunate guesses about the future. To become risk takers, individuals first need to establish some control over their environment through various forms of collective action. From this perspective, institutions matter for two reasons. First, in the fashion outlined by North, they create defined spaces and areas of freedom in which individuals can act with the expectation that their actions will be seen as legitimate and the benefits they generate will be protected. Second, following Commons and Schackle, institutions provide a framework permitting the cooperation and collective action that enhances people's control and power over the future. This raises a vital question: if institutions structure and make possible individual choices, how can we then conceive of individuals making maximising choices outside of the framework that institutions have created?

Thus, the insights of Commons and Shackle raise important issues about how institutions interact with individual choices. Two possible extremes are useful in illustrating how the conceptual relationship between these two factors will determine the possibilities for a development approach based on institutional reform. Either institutions determine choices, in which case institutional change can only occur via dramatic transformations undertaken by powers that somehow exist beyond the reach of the determining institutional environment, or individuals choose the institutions that work best for them, in which case the institutional environment will tend to change in accordance with the needs of a changing economic system. In this extreme case, institutions would not really matter at all- they would merely be a reflection of the economic need to reduce transaction costs. 
In the 1990s, North began to shift his position closer to the one advocated by Commons. He now believed that institutions evolved incrementally and connected the past with the present and the future. The economic decisions of individuals, he thus realised, could only be understood through sequential study, not in terms of maximising decisions made in a particular moment of time (David 1994:207).

Evolutionary perspectives on economic changes see institutions as influencing but not completely constraining people's choices. Richard Nelson provides a perspective that helps us conceptualise the ways in which individual choices and institutional constraints interact to shape the patterns of change. In Nelson's (2005:159) terms, institutions channel the direction of change. Many choices, he argues, are made routinely, without much conscious thinking. In addition, institutional innovation is risky. For this reason, people will usually see it as prudent to work within established norms and rules, seeking incremental rather than wholesale change. Therefore, it is likely that self-interested choices are to a large extent shaped by influential circumstances that pre-exist and structure those choices.

Despite these constraints, institutional change is always possible, and even likely. As the external environment changes, people will need to adapt existing institutional arrangements to meet the new challenges posed by the changing environment. If they do not, organisations and institutions will become a subject to 'pressures and stresses that may cause them to abruptly collapse and dissolve or to be captured, dismembered and ingested by other competing organisations' (David 1994:218). More recently, North, Wallis and Weingast (2009:12) have argued that change is likely and even frequently necessary despite institutional rigidities. They point out that societies are regularly subject to unpredictable challenges. Changes in factors like climate, relative prices and neighbouring groups as well as changes like the identity and character of leaders, internal feuds and disputes, and relative prices frequently require societies to adjust their institutional environments and to find innovative solutions.

We can see that institutions make effective individual actions possible. As a result, institutions will invariably affect the choices that individuals make. It will, therefore, be impossible to simply change the institutional environment in accordance with the advice of experts or because a new institutional arrangement is economically more efficient. Societies will not automatically be transformed into a uniform, predictable way in response to new economic signals. Nor will change necessarily emerge as the result of initiatives undertaken by a few entrepreneurial individuals. Both those things can be agents of change, but they will not be successful unless other changes also take place in the way in which people are organised and related to one another. Change will necessarily always be a social, pathdependent process.

\section{The prospects for government-led institutional change}

If institutional change is difficult to achieve and pathdependent, it is unlikely that change will come about readily and as intended - through the efforts of well-meaning politicians setting out to create a new property rights regime at the behest of enlightened foreign advisers. Such a process is made even more unlikely, if we accept the validity of the political-economy approach that underpins some of the more recent approaches to institutional economics.

In their book, Why Nation's Fail, Acemoglu and Robinson employed a well-established political-economy approach (Bates 2001; Buchanan \& Tullock 1962) to explain why certain institutions emerge, and why change is extremely difficult. 'One lesson is clear' they argue, 'powerful groups often stand against economic progress and against the engines of prosperity'. Such groups set up extractive institutions that allow them to use political power to extract a surplus from others and protect elites from current and future threats. Setting up property rights for a limited section of the population can be one of the ways in which such extraction takes place. Furthermore, those who suffer from bad economic institutions cannot hope for absolutist states to voluntarily change political institutions and redistribute power in society (Acemoglu \& Robinson 2012:86-87).

In a 2008 paper, Acemoglu and Robinson reached pessimistic conclusions about the possibilities for achieving institutional reform. They argued that attempts to reform specific economic institutions are unlikely to be effective if they are not accompanied by fundamental changes in the political equilibrium. Those who stay in power will find ways to dampen the effects of the reforms or work their way around them by employing other institutions to facilitate their extractive activities. Even when real changes in de jure power take place, the persistence of de facto power will allow elites to prevent any real change, for example, as happened after the emancipation in the American South. Finally, more fundamental shifts in power may also not be sufficient to bring about real change. In the wake of a major shift in power, new, incoming elites may find it in their interest to keep existing extractive institutions in place, or during the process of overthrowing existing elites, forces were unleashed that created equally bad or sometimes even worse elites. Once they have seized power, they will put in place their own forms of extraction.

While Acemoglu and Robinson (2008) provide a strongly functionalist, and perhaps overly pessimistic, picture of the possibilities of fundamental change, they do produce a powerful corrective to those who, like De Soto in his roving expert mode, see change as driven mostly by wellmeaning politicians educated by globe-trotting, propertyrights experts. 


\section{Transforming institutions and expanding property rights}

Hernando De Soto's main achievement is the attention he has drawn to the absence of property rights - as opposed to a lack of income or initiative - as a significant barrier preventing people from moving out of poverty. However, De Soto has been less successful in providing a clear guide for developing countries to follow in their quest to acquire the kinds of property rights he sees as essential. This may be the result of an overly simplistic understanding of how institutions change. The central idea that emerges from the review undertaken in this article is that institutions are socially determined processes. Creating the right kind of institutional change will not be a simple process that can be imposed either by enlightened rulers or by rational individuals, although both will have a role to play. Instead, establishing property rights will be contingent on complex and difficult to manage social processes. This leads to the conclusion that the construction of an effective property rights system is unlikely to be achieved via a top-down, state-driven planning approach. Instead, such an integrated system will be shaped by a complex interplay of cultural, political and economic conditions that the state can encourage and interact with, but cannot simply create from scratch.

Elements of such an approach can be found in De Soto's work, but he does not follow through on these insights and ends up advocating an unrealistic, unhelpful approach for transforming property rights. De Soto (2000:68) outlined the essence of the development challenge as overcoming the arrangements that make capitalism in developing countries a private club, open to a privileged few, and prevent the majority from entering the formal property system.

The challenge for those whose aim is to achieve development is, therefore, to lift, smash or (more gradually) expand 'the bell-jar'. But how is this to be achieved? In his role as a global expert, De Soto tends to regard the solution as a matter of persuading the authorities and putting in place the technical elements behind a more effective and more encompassing legal system. In The Mystery of Capital, he concludes his chapter entitled 'The Mystery of Political Awareness' with the optimistic belief that once governments of developing countries accept that the core problem is the inaccessible legal system, they can begin to 'catch the wave' of capitalist development (De Soto 2000:107).

The programme that De Soto (2000:168-169) puts forward for the governments that have seen the light is very detailed, and incorporates some recognition of the difficult negotiations that have to take place. But it still comes across as a centrally conceived plan that can be implemented in a linear, topdown fashion by enlightened leaders and their expert consultants. He provides a detailed programme in which he expects government to move through: a 'discovery strategy', during which they will map the informal sector and calculate the costs of informality; a legal strategy in which government takes charge, creates agencies that will permit rapid change and builds consensus across society; an operational strategy that builds up the government's capacity, initiates a communication strategy that will overcome the opposition of those with vested interests in the status quo and creates a sophisticated record keeping process.

These all sound like useful activities and the extensive list clearly demonstrates that De Soto recognises some of the complexities associated with the extension of property rights. However, it is surely wildly optimistic to expect developing countries to pull off this herculean feat. First, very few, if any, governments will have sufficient capacity to implement effectively even half of these tasks. Second, it will surely require much more than 'communication strategies' to get groups of people to change their habits towards one another and abandon their perceived or real material interests. Third, as Hayek pointed out repeatedly, a lot of information that officials need to 'discover' is too tacit to be readily accessible to government planners.

A careful reading of the rest of the Mystery of Capital, as well as the earlier The Other Path, however, provides insights into the expansion of property rights that contradict this optimistic belief in government's ability to eradicate the bell-jar effect through a deliberate top-down process. De Soto (2000:34), in fact, revealed that the process of creating property is contingent on complex social interactions. For example, in his analysis of the inclusive property system that emerged in 'the West', he points out that the legal system in which assets could be regarded as capital emerged out of extremely complex and difficult to visualise processes. 'The genius of the West', he argues, 'was to have created a system that allowed people to grasp with the mind values that human eyes could never see and to manipulate things that hands could never touch' (De Soto 2000:34).

Clearly, property rights in the West were not the product of a planned, centrally conceived government programmes. They emerged, instead, out of thousands of pieces of legislation that gradually came together to form an all-encompassing property system. This required social and political shifts, both within the state and among the people who became part of and had to accommodate themselves to the system. The creation of property rights in the West involved fundamental social transformations.

The crucial issues at work here can be drawn out further by comparing property rights conflicts in Peru with those in the USA, as described in De Soto's work. De Soto describes the Peru conflicts in his book The Other Path and the US conflict in The Mystery of Capital.

The following paragraph from The Other Path (De Soto 1989:91) sums up the unremitting conflict between illegal street traders and local Peruvian states:

... The fluctuation between persecution and cooperation, which
began in colonial times, has shown - century after century - that
the authorities do not understand what is happening. For more
than fifty years, both the central and the municipal governments 
have been exchanging responsibilities without ever arriving at a coherent policy which will allow them to act independently of their political interests. This has completely distorted incentives, politicising a group of vendors and delaying the majority's march towards formal business activity. ... Over the years [the vendors] waged major campaigns to make their businesses legally secure. The first such battle was for special rights of ownership. The second was the battle for markets; it brought the majority of vendors ... into conflict with the state which, allied with a minority of these vendors, was prepared to politicize the system in order to avoid losing influence as vendors became private owners. In both battles we see the confrontation between an insurgent, informal Peru and the status quo in one or another of its political manifestations.

In the USA, by contrast, illegal squatters and various state bodies moved inexorably closer to one another until the squatters eventually became legal property owners. The reason, as the quote below reveals, was that entrepreneurial politicians saw squatters as voters who could sway an election. To capture these votes, some of the politicians set out to meet the demands of the squatters. At the same time, when the squatters saw that their demands could be accommodated within the context of the established democratic system, they modified their demands and allowed themselves to become a part of the system. De Soto (2001:136) described the process as follows:

American politicians had several choices. They could continue to try to thwart or ignore extralegals, grudgingly make concessions or become champions of extra-legal rights. The expansion of occupancy laws - recognizing a right to land based on improvements made on it - throughout the United States during the first sixty years of the nineteenth century suggests that politicians increasingly followed the last course. The history of the adoption of occupancy laws in the United States is the history of the rise of extralegals as a political force.

De Soto places his emphasis on the social movements that emerged in the USA and demanded the extension of property rights. But his two books show that such social movements emerged on both the North and the South American continent. What also matters is the nature of the political system in which these movements emerged, how the movements engaged the state and vice versa.

The essential difference between the two cases is this: In Peru, the state sought to extend its power and influence, and regarded traders as either potential threats that had to be neutralised or as potential clients. Whereas in the USA, the state saw squatters primarily as potential voters. As a result, the relationship between the state and the trader in Peru cycled through phases of co-option and conflict, whereas in the USA the state saw it in its best interest to amend the legislation and to recognise the legal rights of squatters. In the USA, squatters became a part of the legal system. In Peru, most of the traders remained illegal. In the USA, democracy worked. In Peru democracy, always weak and intermittent, was undermined by clientelism and power politics.

From this, I derived the idea that a crucial component of the development process is the promotion of reforms that facilitate increasing levels of cooperation between the state and the poor. This has to be achieved in such a way that, rather than imposing a fully-formed plan onto the poor, the state is able to listen to and adjust to the needs and concerns of the poor people. At the same time, it must not be assumed that the poor have a clear, well informed and unified position on what their interests are. What is required is a dialogue in which the state has information and solutions to offer but at the same time gives people the space to build on the initiatives in which they are already engaging, and to formulate a way forward for themselves. What has to be avoided, furthermore, are populist practices in which the state gives into demands for quick fix solutions irrespective of the broader, long-term consequences. In addition, the state has to display a commitment to extending and in some instances re-distributing property rights, without undermining, at an abstract level, the notion that property rights are ultimately secure. In other words, the property system needs to expand and transform without undermining the integrity of property as an abstract right.

To be fair, De Soto (2006:2) has admitted that achieving development is 'more difficult than we thought' and asserted that:

... the real problem is how do you actually mesh [institutions] with people's beliefs? What adjustment do you have to make so that a good rule becomes applicable and culturally recognisable in your own country?

In doing so, he has lent weight to the interpretation offered in this article.

There is no easy, quick-fix solution for creating property rights. To develop practical ways of creating property rights, we need to develop a historical understanding of why bureaucracies become inaccessible. Rather than simply assuming that states will see the light if we tell them the answer, we need to understand how they got to, where they are and what specifically needs to be changed to improve the situation. It also requires initiating localised mobilisation and experimentation.

Instead of the top-down planning approach that De Soto has advocated, we should heed Hirschman's (1981:234) warning against 'overconfidence in the solvability of all problems', and instead help people to confront their own difficulties. At the national level, it is most important for the government to provide a commitment to democracy and the sanctity of property rights. The commitment to democracy must include not just the insurance of free and fair elections, but also an acceptance that no one is above the law, and that people are free to express their opinions and governments are obligated to take those opinions into account.

The sanctity of property rights is even more complicated. In countries where De Soto's 'bell-jar' effect prevails, it is necessary to accept that some redistribution of rights needs to occur, and that disputes over rights need to be settled. The state must therefore move away from seeing existing 
rights as immutable, and must rather develop a language in which rights can be shifted and renegotiated without such processes weakening the idea that newly established rights are secure. Even if these new rights have been achieved with the assistance of the state, said state must avoid the temptation to prescribe how recipients should use their new resource; nor should the state retain the right to redistribute resources in the future, as this will serve to undermine property rights in the long term.

\section{The situation in South Africa}

In South Africa, both the land reform programme and the housing policy have sporadically grappled with ways of minimising the disruption of property rights and providing the beneficiaries with new, secure rights. But the commitment to these principles has been neither strong nor consistent enough. In the case of land reform, there has been a constant tension between elements that have sought to protect property rights and those that have, deliberately or not, undermined them. The original land reform programme, under the influence of World Bank advisers, protected property rights by constraining the ability of the state to expropriate existing land owners (Greenberg 2003). At the same time, however, there was a deliberate policy to prevent land reform beneficiaries from acquiring individual titles. They were saddled instead with Communal Property Associations that all but obliterated the ability of beneficiaries to use their newly acquired plots as an economic asset (Schirmer 2009). Later, in 2000s, this policy was reformed and it became possible for beneficiaries to receive titles. Observers also pointed to a more pragmatic embrace of markets emerging within the Department of Land Affairs during this time (see James 2007). Such officials found ways to enable those who had acquired informal rights to take their place alongside property holders.

These trends were, however, directly contradicted by government's ongoing attempts to restore chiefly rights over the old homeland areas, and by the massive inefficiency and seemingly infinite extension of the restitution process (Claassens \& Cousins 2008). Originally, the right of black South Africans' forced off their land as a result of segregationist laws to reclaim their land through a special land court was supposed to end in 1998. However, since then the deadline has been repeatedly extended, and many claims have taken an eternity to process, leaving in limbo those who occupy the claimed land. Some who bought land in the 2000s that they were assured was not under claim subsequently found themselves in court fighting an expensive claim.

Rather than the extension of property rights, the 'bell-jar' in the South African countryside may in fact be shrinking as the insecure tenure of the old homelands is spreading out into old white farming areas where individual tenures were once secure. Two major causes of this pattern are theft and tenure insecurity created by the state's indecisiveness. One farmer from the Middelburg area maintained that farms bordering old homelands are lying fallow. No one wants to invest in them because of extensive crime and squatting (James 2007:233). On these 'frontiers' land is losing value, and the owners have the choice of either selling their land to the government or allowing the land to be occupied by squatters. These outcomes are expanding uncertainty about property rights, which is undermining the position of both the black and white farmers, and serves to strengthen, rather than weaken, the distinction between farming in 'white areas' and farming in the old homelands.

Both the practice of and discussions around land reform in South Africa have been dominated by the goal of redistributing assets and compensating people for the horrors they experienced at the hand of segregation and apartheid policies (Ntsebeza \& Hall 2007). Given South Africa's history, this is perfectly understandable and justifiable. However, rather than just looking back, our post-Apartheid policies need also to enable a better future for the rural poor. The unfortunate but undeniable outcome of past policies was the de facto destruction of most black South Africans' rural livelihoods while they were nevertheless forced to reside in nominally rural areas. Since democracy millions have moved to urban areas, but large numbers nevertheless remain in the original 'homeland' areas where they face very high unemployment rates and very few economic prospects.

Providing property rights to those stuck in unproductive 'rural' areas could be a way to accelerate urbanisation, allowing rural residents to either sell their land or use it as an asset to finance migration to or settlement closer to urban economic opportunities. Such an approach is, again, unlikely to be a panacea, and the blanket imposition of private rights in the homeland areas will cause more upheaval and harm than benefits. Instead, as advocated throughout this article, what is required is a gradual bottom-up approach; an approach that takes rural realities and demands from some for the preservation of customary, security enhancing arrangements into account. ${ }^{3}$ What is vital, if we are to move towards a more equitable property rights regime, is that policies and analyses move away from thinking about land reform as a purely rural or agricultural question, and focus instead on ways to strengthen the links between rural and urban areas. ${ }^{4}$ Undoubtedly, as Hart and Sitas (2004) pointed out some time ago, maintaining access to rural homes and some land is partly driven by a desire to maintain forms of security in the face of the volatile nature of urban living and labour markets. What we do not know, however, is the extent to which rural insecurity, caused by undefined property rights, prevents poor people from using their assets to increase their capacity and their ability to gain access to urban opportunities.

In housing policy, a similar ambivalence within the state has been very evident. Originally, the housing authorities were 3.See Cousins (2008) and Kingwell (2008) for details on these types of demands.

4.See Hart and Sitas (2004) for an important but unfortunately still exceptional contribution to thinking about rural and urban linkages. 
mostly unconcerned about the property rights of those who received the township-like RDP housing, and in fact put limits on the rights of recipients to use their houses as business premises, to rent their houses and to sell their houses. As already noted, a greater emphasis on property rights has now emerged, but ambivalence remains at the highest levels. In 2004, the department set out to:

... promote the realisation of housing as an asset and support households in their efforts to use their house for more than shelter, as a vital component of their livelihood strategy, the development of their business and their long term financial planning. (Department of Housing 2004:11)

Despite this, elements of the policy continue to work against widening the bell-jar. For example, beneficiaries are still prevented from selling their house for 5 years after receiving it. As recently as 2008 Minister Sisulu directly contradicted her reverence for De Soto and his principles by threatening to repossess RDP houses that owners rented out. She also described selling RDP housing as 'a criminal act' (Adebayo 2012).

Among informal traders, who are subject to municipal laws and local policing, the situation is even worse. The city of Johannesburg's regulations have been characterised as restrictive, non-consultative and orientated towards enforcement rather than development. The lack of willingness to recognise street traders as legitimate businesses was demonstrated brutally in 2013 by 'Operation Clean Sweep', when 7000 traders were chased by police from the streets of Johannesburg. In Pretoria, in 2014, police allegedly attacked traders and confiscated their stock, after the traders insisted on being issued with fines rather than being removed from their trading posts. One trader was shot dead. ${ }^{5}$

The situation in South Africa is that, despite incidents of consultation and isolated efforts to expand property rights, government is becoming increasingly disconnected from poor communities. This emerges clearly from the growing number and rising violence of 'service delivery protests'. The reasons for these protests are complex. They are driven by a variety of factors including political faction fighting, corruption and xenophobic tensions. However, at the broadest level, these protests represent an attempt by poor communities, many located in informal settlements, to be heard and to be included. A recent analysis found that $80 \%$ of 2014 protests took violent forms, including damage to property and intimidation. In 2007 , only $50 \%$ of protests had turned violent. According to one analysis, the violence of protests is a direct result of the unresponsiveness of local governments. Protesters have no expectation that their grievances will be heard, so they move directly to violent protest instead of going through the run-up phase of petitions and marches. ${ }^{6}$

5.Thapelo Lekgowa and Greg Nicolson, Operation Clean Sweep, http://www. dailymaverick.co.za/article/2013-12-06-operation-clean-sweep-johannesburgmetro-police-arrests-human-rights-lawyer/\#.VhI4Q-yqqko

6.Niki Moore, The Civic Protest Barometer, Episode Three: What causes residents to revolt? http://www.dailymaverick.co.za/article/2015-03-17

\section{Expanding property rights in South Africa}

As I have argued repeatedly, expanding property rights is not a quick fix solution. There are many organised interests, and difficult to change tensions and conflicts that stand in the way. However, there should be a broad commitment within government to bring about the kind of integrated property system that De Soto advocates. Achieving this would finally eradicate one of the most pernicious legacies of apartheid - the denial of property rights to black South Africans' living in homelands and townships.

In the meantime, carefully chosen initiatives at all levels of the state should be encouraged. Potential interventions should be carefully considered in terms of their effect on producing a climate of cooperation and inclusiveness. Programmes that produce a class of threatened property holders on one side and a 'beneficiary group' dependent on the state on the other will not contribute much to eradicating the bell-jar effect.

At the broadest level, the approach should be to find ways of strengthening inclusive attitudes, the extent of democratic accountability, and the expansion and re-distribution of property rights simultaneously, in as many gradual and practical ways as possible.

More specifically, the most important element of this programme will be to make local forms of government more responsive and durable, and less corrupt. In a fascinating analysis that takes account of the opinions of poor people across the world, Narayan, Pritchett and Kapoor (2009:271) have pointed to the importance of making local governments accountable and willing to work with their constituencies. From their extensive research across the developing world, they found that the poor people see an association between their attempts to move out of poverty and the responsiveness of local democratic structures such as the shura in Afghanistan, village executive committees in Tanzania and panchayats in India. Narayan, Pritchett and Kapoor concluded that well-functioning local governments can be dynamic entities that liberalise the economy from below.

A gradual improvement in government's support and advocacy for abstract property rights and the strengthening of accountability and inclusiveness at all levels of the state will promote processes through which states and private individuals find ways to work together. They can then reach a point where people become prepared to accept government's rules and government begins to work on a legal framework that is acceptable to most people. When that happens, the bell-jar will gradually evaporate and the kind of property rights regime endorsed by De Soto will eventually emerge - but it will not be tomorrow and it will not be easy. 


\section{Acknowledgement}

The author hereby gratefully acknowledges the financial support of the National Research Foundation (NRF).

\section{Conflict of interest}

The author declares that he has no financial or personal relationship(s) which may have inappropriately influenced him in writing this article.

\section{References}

Acemoglu, D. \& Robinson, J., 2008, The role of institutions in economic growth, Unpublished Paper, World Bank.

Acemoglu, D. \& Robinson, J., 2012, Why nations fail: The origins of power, prosperity and poverty, Profile Books, London.

Adebayo, P.W., 2012, Still no room at the Inn: Post-apartheid housing policy and the challenge of integrating the poor in South African cities, Unpublished paper.

Angeles, L., 2011, Institutions, property rights, and economic development in historical perspective, Unpublished Paper.

Bates, R.H., 2001, Prosperity and violence: The political economy of development, W. W. Norton, New York.

Buchanan, J. \& Tullock, G., 1962, The calculus of consent: Logical foundations of constitutional democracy, University of Michigan Press, Ann Arbor, MI.

Claassens, A. \& Cousins, B., 2008, Land, power \& custom: Controversies generated by South Africa's communal land rights act, UCT Press, Cape Town.

Commons, J.R., 1950, The economics of collective action, Macmillan, New York.

Cousins, B., Cousins, T., Hornby, D., Kingwill, R., Royston, L. \& Smit W., 2005, Will formalising property rights reduce poverty in South Africa's 'second economy? Questioning the mythologies of Hernando de Soto, PLAAS Policy Brief 18, http:// www.plaas.org.za/publication-categories/pb?page $=8$

David, P., 1994, 'Why are institutions the carriers of history?', Structural Change and Economic Dynamics 5(2), 205-220. http://dx.doi.org/10.1016/0954-349X(94) 90002-7

Department of Housing, 2004, White paper: A new housing policy and strategy for South Africa, viewed 4 September 2014, from http://www.dhs.gov.za/sites/ default/files/legislation/Policies_Housing_White_Paper.pdf
De Soto, H., 1989, The other path: The invisible revolution in the third world, Harper \& Row, New York.

De Soto, H., 2001, The mystery of capital: Why capitalism triumphs in the west and fails everywhere else, Bantam Press, London.

De Soto, H, 2006, Hernando De Soto Interview, Reason Magazine, viewed n.d., from, http://reason.com/archives/2006/02/22/hernando-de-soto-interview/1

Greenberg, S, 2003, 'Land reform and transition in South Africa', Transformation, 54, 41-53.

Hart, G. \& Sitas, A., 2004, 'Beyond the urban-rural divide: Linking land, labour and livelihoods', Transformation 56(3), 31-38. http://dx.doi.org/10.1353/trn.2005. 0020

Hirschman, A.O., 1981, Essays in trespassing: Economics to politics and beyond, Cambridge University Press, Cambridge.

James, D., 2007, Gaining ground: Rights and property in South African land reform, Wits University Press, Johannesburg.

McCloskey, D.N., 2010, Bourgeois dignity: Why economics can't explain the modern world, University of Chicago Press, Chicago, IL.

Narayan, D., Pritchett, L. \& Kapoor, S., 2009, Moving out of poverty: Success from the bottom up, World Bank, Washington, DC.

Nelson, R., 2005, Technology, institutions and economic growth, Harvard University Press, Cambridge, MA.

North, D.C., 1993, 'Institutions and economic performance', in U. Maki, B. Gustafsson \& C. Knudsen (eds.), Rationality, institutions \& economic methodology, Routledge, London.

North, D.C., 1977, 'Markets and other allocation systems in history: The challenge of Karl Polanyi', Journal of European Economic History 6, 703-716.

North, D.C., Wallis, J. \& Weingast, B., 2009, Violence and social orders, a conceptual framework for interpreting recorded human history, Cambridge University Press, Cambridge.

North, D.C. \& Weingast, B., 1989, 'Constitutions and commitment: The evolution of institutions governing public choice in seventeenth-century Britain', The Journal of Economic History 49, 4, 803-32.

Ntsebeza, L., \& Hall, R., 2007. The land question in South Africa: The challenge of transformation and redistribution, HSRC Press, Pretoria.

Schirmer, S., 2009, 'Land reform: The state we are in', African Studies 68, 3, 465-478.

Shackle, G.L.S., 1990, 'Keynes and the nature of human affairs', in J.C. Wood (ed.), John Maynard Keynes: Critical assessments, vol. 1, Routledge, London.

Tomlinson, M., 2005, 'Title deeds not a magic wand', Business Day, 10 August.

Vanberg, V., 1989, 'Carl Menger's evolutionary and John R. Commons' collective action approach to institutions: A comparison', Review of Political Economy 1 334-360. http://dx.doi.org/10.1080/09538258900000025 